\title{
Endophytic Bacteria Improve Root Traits, Biomass and Yield of Helianthus tuberosus L. under Normal and Deficit Water Conditions ${ }^{\text {[ }}$
}

\author{
Junthima Namwongsa ${ }^{1}$, Sanun Jogloy ${ }^{2}$, Nimitr Vorasoot $^{2}$, Sophon Boonlue ${ }^{1}$, Nuntavan Riddech ${ }^{1}$, and \\ Wiyada Mongkolthanaruk ${ }^{1 *}$ \\ ${ }^{1}$ Department of Microbiology, Faculty of Science, Khon Kaen University, Khon Kaen, 40002, Thailand \\ ${ }^{2}$ Department of Plant Science and Agricultural Resources, Faculty of Agriculture, Khon Kaen University, Khon Kaen, 40002, Thailand
}

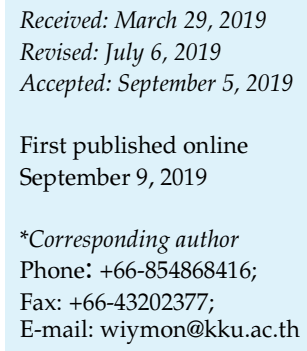

S upplementary data for this paper are available on-line only at http://jmb.or.kr.

pISSN 1017-7825, eISSN 1738-8872

Copyright@ 2019 by

The Korean Society for Microbiology and Biotechnology

\begin{abstract}
Drought is more concerned to be a huge problem for agriculture as it affects plant growth and yield. Endophytic bacteria act as plant growth promoting bacteria that have roles for improving plant growth under stress conditions. The properties of four strains of endophytic bacteria were determined under water deficit medium with $20 \%$ polyethylene glycol. Bacillus aquimaris strain 3.13 showed high 1-aminocyclopropane-1-carboxylate (ACC) deaminase production; Micrococcus luteus strain 4.43 produced indole acetic acid (IAA). Exopolysaccharide production was high in Bacillus methylotrophicus strain 5.18 while Bacillus sp. strain 5.2 did not show major properties for drought response. Inoculation of endophytic bacteria into plants, strain 3.13 and 4.43 increased height, shoot and root weight, root length, root diameter, root volume, root area and root surface of Jerusalem artichoke grown under water limitation, clearly shown in water supply at $1 / 3$ of available water. These increases were caused by bacteria ACC deaminase and IAA production; moreover, strain 4.43 boosted leaf area and chlorophyll levels, leading to increased photosynthesis under drought at 60 days of planting. The harvest index was high in the treatment with strain 4.43 and 3.13 under $1 / 3$ of available water, promoting tuber numbers and tuber weight. Inulin content was unchanged in the control between well-watered and drought conditions. In comparison, inulin levels were higher in the endophytic bacteria treatment under both conditions, although yields dipped under drought. Thus, the endophytic bacteria promoted in plant growth and yield under drought; they had outstanding function in the enhancement of inulin content under wellwatered condition.
\end{abstract}

Keywords: Drought, inulin, Jerusalem artichoke, plant promoting endophytes

\section{Introduction}

Jerusalem artichoke (Helianthus tuberosus L.), also called the sunchoke, sunroot, or kaentawan (in Thailand), accumulates inulin in tubers in the same way as root chicory (Cichorium intybus var. sativum) and globe artichoke (Cynara cardunculus var. scolymus). The plant is native to North America and is currently grown in the USA, Canada, France, Italy, Russia, China, India and Thailand. It adapts well to wide ranges of climates, including arid conditions. Water, however, is a vital component of plant growth; it is the source of hydrogen atoms in all organic compounds, operating as a solvent and transporting nutrients and minerals within the plants in order to sustain life [1]. Drought has a direct impact on water resources and consequently agriculture, causing stress to plants and decreasing yield [2]. With water deficiency the tuber yield of Jerusalem artichoke is reduced, leading to a reduction in both the quality and quantity of inulin. Inulin has various benefits, such as for health, forage production, medicinal uses, fuel production and as industrial raw materials. The effect of water regimes on biomass, tuber yield, inulin yield 
and drought tolerance were investigated with different genotypes of Jerusalem artichoke. Genotypes, JA5, JA125 and JA60 were tolerant to severe drought and recommended for drought conditions. Another genotype, HEL65, gave high inulin content under field capacity water levels and tolerated moderate drought, showing high inulin content under $50 \%$ and $25 \%$ of soil available water [3]. The positive qualities of this genotype should be developed by breeding. Therefore, this genotype, HEL65, was chosen for this work as it still survived in moderate drought and could be enhanced the growth and yield under drought by plant growth promoting bacteria. Also, this genotype was popular for edible vegetable and high inulin production which made high product value for this genotype.

Bacteria co-evolved with plants grown under stress conditions and provide significant benefits to the plant. These beneficial microorganisms, which may grow in the rhizosphere, rhizoplane, phylosphere, endophytes or freely in the soil, are termed plant growth promoting bacteria, PGPB. Rhizobacteria in particular showed potential to enhance plant growth, including under drought conditions. The bacteria alleviate drought stress in plants by producing phytohormones, 1-aminocyclopropane-1carboxylate (ACC) deaminase, exopolysaccharides (EPS) and osmolytes [4]. Plants produce IAA to control growth. However, when the plant is in a stress condition, a hormonal imbalance is observed, which influences abscisic acid (ABA) synthesis. Consequently, IAA levels decrease, whilst ABA levels increase [5], leading to growth resting. ACC-deaminase plays an important role in reducing stress in plants by degradation of ACC, which is a precursor of ethylene production. When plants are stressed, they accumulate more ethylene for growth inhibition. The PGPB use sources of carbon and nitrogen from ACC degradation. As the level of ACC decreases due to bacterial degradation, the level of ethylene in the plant also decreases. This helps the plant to protect itself from environmental stress [6]. Bacteria can survive under stress conditions due to the production of EPS, which protects microorganisms from water stress by enhancing water retention and regulating the diffusion of organic carbon sources $[7,8]$.

Endophytic bacteria are PGPB and can also stimulate plant growth by increasing root length and root volume, increasing the surface area for absorbing water and nutrients. They also produce substances or hormones, such as indole acetic acid (IAA), ACC-deaminase, and EPS which assist plant survival in stress conditions. This study analysed native endophytic bacteria isolated from
Jerusalem artichoke, investigating the properties involved in drought tolerance and the effects of endophytic bacteria on plant growth promotion.

\section{Materials and Methods}

\section{Cultivation of Endophytic Bacteria}

Four strains of endophytic bacteria isolated from the leaf and stem of Jerusalem artichoke were identified as Bacillus aquimaris 3.13 (MH973229), Micrococcus luteus 4.43 (MH973230), Bacillus sp. 5.2 (MH973227) and Bacillus methylotrophicus 5.18 (MH973231) from previous study [9]. The bacteria were grown in nutrient broth (NB) with agitation of $150 \mathrm{rpm}$ at $30^{\circ} \mathrm{C}$ for $24 \mathrm{~h}$. The cell pellet was collected by centrifugation at 5,000 rpm for $15 \mathrm{~min}$ and then was washed twice with $0.85 \% \mathrm{NaCl}$, and the cell suspension adjusted with sterile distilled water equal to McFarland scale 0.5 $\left(1 \times 10^{8} \mathrm{CFU} / \mathrm{ml}\right)$ as bacterial inoculums.

\section{Property of Endophytic Bacteria for Response to Water Deficit}

Determination of IAA production. One percent of bacterial inoculums was transferred into NB supplemented with $1 \mathrm{mg} / \mathrm{ml}$ of L-tryptophan and NB with $20 \%$ of polyethylene glycol 6000 (PEG6000) supplemented with $1 \mathrm{mg} / \mathrm{ml}$ of L-tryptophan. The culture was incubated at $30^{\circ} \mathrm{C}$ with agitation and the supernatant collected at 24,48 , and $72 \mathrm{~h}$ by centrifugation at $10,000 \mathrm{rpm}$ for $10 \mathrm{~min}$. One milliliter of the sample was mixed with $1 \mathrm{ml}$ of Salkowski's reagent $\left(12 \mathrm{~g} / 1 \mathrm{FeCl}_{3}\right.$ in $\left.35 \% \mathrm{H}_{2} \mathrm{SO}_{4}\right)$ and left in darkness for $30 \mathrm{~min}$. Absorbance of the mixture was detected at $530 \mathrm{~nm}$ by spectrophotometer and the IAA concentration calculated from standard curve.

Determination of ACC deaminase. One percent of bacterial inoculums was transferred into $5 \mathrm{ml}$ of $\mathrm{NB}$, incubated at $30^{\circ} \mathrm{C}$ for $24 \mathrm{~h}$ with agitation. The cell pellet was collected and washed twice with $0.1 \mathrm{M}$ Tris- $\mathrm{HCl}$ ( $\mathrm{pH}$ 7.5). After that, the cell was transferred into two separate flasks, each containing $2 \mathrm{ml}$ of DF medium with $3 \mathrm{mM}$ ACC. $20 \%$ of PEG6000 was added to one flask. The culture was incubated at $30^{\circ} \mathrm{C}$ for 24,48 , and $72 \mathrm{~h}$ with agitation at $150 \mathrm{rpm}$. The cell was collected and washed twice with $0.1 \mathrm{M}$ Tris$\mathrm{HCl}(\mathrm{pH} 7.5)$ and suspended in $200 \mu \mathrm{l}$ of $0.1 \mathrm{M}$ Tris- $\mathrm{HCl}(\mathrm{pH} 8.5)$. The cell suspension was mixed with $5 \%$ of toluene; and then the $30 \mu \mathrm{l}$ of cell mixture was transferred into $5 \mu \mathrm{l}$ of $0.3 \mathrm{M} \mathrm{ACC}$ with incubation at $30^{\circ} \mathrm{C}$ for $30 \mathrm{~min}$. The control was composed of the cell mixture without ACC as a substrate. For blank flask, the mixture was $0.1 \mathrm{M}$ Tris- $\mathrm{HCl}(\mathrm{pH}$ 8.5) with ACC substrate. After incubation, ACC deaminase was determined as described by Ali et al. [10] using $\alpha$-ketobutyrate for standard curve.

Determination of exopolysaccharide production. One percentage of bacterial inoculums was transferred into NB in two flasks, with or without $20 \%$ of PEG6000, and incubated at $30^{\circ} \mathrm{C}$ for $96 \mathrm{~h}$ with agitation of $150 \mathrm{rpm} .10 \mathrm{ml}$ of $0.85 \% \mathrm{KCl}$ was added into the culture to reduce viscosity. The supernatant was kept by centrifugation at 10,000 rpm for $25 \mathrm{~min}$ and filtrated through filter 
membrane (Whatman No. 4). The filtrate was transferred into a dialysis bag for dialysis with sterile water at $4^{\circ} \mathrm{C}$ and centrifuged again to collect the supernatant. Three volumes of absolute ethanol were added to the supernatant and then centrifuged before collection. The dialysis step was repeated 3 times. After that, the total carbohydrate content of the supernatant was determined following the method of Dubois et al. [11] using glucose as a standard curve.

Determination of proline production. One percentage of bacterial inoculums was transferred into NB in two flasks, with or without $20 \%$ of PEG6000, and incubated at $30^{\circ} \mathrm{C}$ for $24 \mathrm{~h}$ with agitation at $150 \mathrm{rpm}$. For proline detection, the cell was separated from supernatant by centrifugation at $10,000 \mathrm{rpm}$ for $10 \mathrm{~min}$ according to Bates et al. [12]. The cell pellet was washed with sterile water then $(0.5 \mathrm{~g})$ mixed with $2 \mathrm{ml}$ of $3 \%$ of sulfosalicylic acid by vortex mixture before filtration through a membrane (Whatman No. 4) to collect the filtrate. The $2 \mathrm{ml}$ of samples (the supernatant or the filtrate) was added into $2 \mathrm{ml}$ of ninhydrin acid and $2 \mathrm{ml}$ of glacial acetic acid. After boiling at $100^{\circ} \mathrm{C}$ for $60 \mathrm{~min}$, the mixture was cooled on ice and $4 \mathrm{ml}$ of toluene added. The color detected in the upper phase of the mixture was at $520 \mathrm{~nm}$ which compared with proline standard.

\section{Applying Endophytic Bacteria for Promoting Plant Growth in} Pot Experiment under Drought Stress

Soil preparation. Soil was air dried and then passed through a $2 \mathrm{~mm}$ sieve. This soil was loamy sand with $\mathrm{pH} 5.11$, electrical conductivity $0.02 \mathrm{dS} \mathrm{m}^{-1}$, cation exchange capacity $7.88 \mathrm{c} \mathrm{mol} \mathrm{(+)}$ $\mathrm{kg}^{-1}$ and organic matter $0.44 \%$. The soil nutrient obtained total $\mathrm{N}$ $0.08 \%$, total P $80 \mathrm{mg} \mathrm{kg}^{-1}$, total $\mathrm{K} 797.46 \mathrm{mg} \mathrm{kg}^{-1}$, available $\mathrm{P}, \mathrm{K}$ and Ca 2.57, 43.85 and $260 \mathrm{mg} \mathrm{kg}^{-1}$, respectively. The soil was packed into a pot (15 inch diameter, 11 inch depth) divided into 2 layers; $16.5 \mathrm{~kg}$ of soil was put at the bottom of the pot with a spacing of $50 \mathrm{~cm}$ from top of the pot. A drip line was installed and covered with soil $(6.5 \mathrm{~kg})$. Plastic tubes were connected with the drip line and used to supply water to the surface soil. Water was supplied at field capacity level before 1 day of planting.

Seedling, planting and inoculation of endophytic bacteria. Pot experiments were conducted in Agronomy farm at Faculty of Agriculture, Khon Kaen University between April - September, 2017. The experiment was arranged in factorial in randomized complete block design with 4 replications and 4 pots per each replication. The genotype of Jerusalem artichoke used in this study was HEL65, prepared by cutting tubers into small pieces with $4-5$ buds each. The tuber pieces were incubated in burnt rice husk in plastic boxes for 7 days and well-watered to induce germination. The germinated seedlings were transferred into a mixture of soil and burnt rice husk (1:1) in plastic trays and wellwatered until the seedlings had 2-3 leaves (about 7 days). The seedlings were transplanted into the pot with field capacity of watering for 7 days before the application of bacterial inoculums. The endophytic bacteria were prepared and adjusted to McFarland scale 0.5 ; then $5 \mathrm{ml}$ of the inoculums were poured into the seedling in each pot, except for the control which was inoculated with $5 \mathrm{ml}$ of water. The inoculums were added to each pot once again 30 days after planting, before water limitation began.

Water management. Three levels of watering were used in this experiment. W1 referred to well-watered, equivalent to the crop water requirement (ET crop, $\mathrm{mm} /$ day). This was calculated by following Doorenbos and Pruitt [13]. W2 referred to watering 2/3 and W3 as $1 / 3$ of the amount supplied under W1 $(2 / 3$ and $1 / 3$ available water $(\mathrm{AW}))$. Where, ETcrop $=\mathrm{ETo} \times \mathrm{Kc}$ which ETo $(\mathrm{mm})$ is evapotranspiration of a reference plant calculated by pan evaporation method; $\mathrm{Kc}_{\mathrm{c}}$ is the crop water requirement coefficient for sunflower at various growth stages. As the crop coefficient of Jerusalem artichoke is not available, that of the sunflower (a closely related species) was chosen instead. The water was supplied at $\mathrm{W} 1$ for 30 days of planting and then the reduction of water supply was applied in W2 and W3 until harvesting time. Soil moisture content was checked to control water supply.

\section{Data Collection}

All parameters were collected at 60 and 140 days of planting. Soil moisture content was measured by collecting soil from reference pots using Micro auger at the depth of $20 \mathrm{~cm}$; samples were incubated at $105^{\circ} \mathrm{C}$ for 3 days. The soil was weighted before and after incubation for calculation of soil moisture content. Relative water content (RWC) was determined to evaluate plant water status following the method described by Janket et al. [14]. SPAD chlorophyll was detected from the second expanded leaves from the top of main stem using SPAD meter (Konica monita, Japan). The same leaves from each pot were analysed for photosynthetic rate, stomatal conductance and transpiration rate using a LI-6400XT portable photosynthesis system (LI-COR Bioscience). Water use efficiency (WUE) was calculated from photosynthetic rate divided by transpiration rate. The height of plants was measured from soil surface to the ends of the top leaves; after that the plants were cut and separated into shoots and roots. The roots were washed with water to remove soil and air dried to remove water. Fresh and dry weights of stem, leaves and root were measured. A random sample of fresh root $(10 \%$ of each treatment) was taken to scan using root scanner (Epson perfection V700 photo) and data analysis was performed by Win Rhizo program for root length, root diameter, root volume and root surface area. A random sample of fresh leaves was measured leaf area by LI-3100C area meter (LI-COR Bioscience).

For crop yield data collected at harvest time (140 days), the tubers were washed with water, separated from roots and air dried to remove water; after that the tubers of each plant were counted and both fresh and dry weight was recorded. The harvest index was calculated following the formula: Harvest index = total dry weight of tubers/ total dry biomass (shoots, roots and tubers). Finally, the dry tubers were ground into fine powder; $2 \mathrm{~g}$ of the powder was added to $25 \mathrm{ml}$ of distilled water, incubated at $80^{\circ} \mathrm{C}$ for $20 \mathrm{~min}$, centrifuged at 4,000 rpm for $5 \mathrm{~min}$ and filtered through 
membrane (Whatman No.4). $500 \mu \mathrm{l}$ of the filtrates was mixed with $0.75 \mathrm{ml}$ of $3 \% \mathrm{HCl}$ and the volume adjusted to $25 \mathrm{ml}$ using distilled water. The mixture was boiled at $100^{\circ} \mathrm{C}$ for $45 \mathrm{~min}$, cooled on ice and the absorbance measured at $390 \mathrm{~nm}$ to compare inulin content from a standard curve of fructose [15].

\section{Statistical Analysis}

All data were subjected to analysis of variance (ANOVA) using STATISTIX8 software. Multiple comparisons of ANOVA with least significant difference (LSD) at $p<0.05$ was performed for bacterial activity. For pot experiments, factorial design was chosen to analyze in ANOVA for all parameters and homogeneity of variance was performed by all pairwise comparisons with LSD method at $95 \%$ and $99 \%$ significant differences for all parameters. Pearson's correlation coefficient between plant parameters was calculated using Excel program and compared the calculated number and critical $\mathrm{r}$ values at probability levels of $p<0.05$ and $p<0.01$.

\section{Results and Discussion}

\section{In Vitro Characters of Endophytic Bacteria in Normal Media and Water Deficit}

Comparison of bacterial activity under normal and stress growth conditions showed that strain 4.43 could produce the highest amount of IAA, and this production was reduced in culture medium with PEG (Fig. 1). In contrast, strains $3.13,5.2$, and 5.18 showed very low amounts of IAA $(<5 \mu \mathrm{g} / \mathrm{ml})$ in both conditions; however, these strains produced IAA better in medium without PEG. This indicated that all strains used tryptophan as a precursor to IAA production (tryptophan dependent pathway). Meanwhile ACC deaminase production was higher in culture medium with PEG than without for all strains, and particularly for strains 3.13 and 5.18 (Fig. 2). The results indicated that ACC deaminase production of the endophytic bacteria was induced under stress condition.

EPS is produced to protect bacterial cells and aid survival in stress environments. Only strain 5.18 produced higher levels of EPS with PEG medium than without (Table 1), and this relates to previous report of cell survival (50\%) on PEG medium at $45^{\circ} \mathrm{C}$ for 30 days [16]. For proline production, strain 4.43 gave the highest proline production in both cell and supernatant; no significance was shown in the supernatant while the proline in cell was higher in the condition with PEG than without PEG significantly (Table 1). The results indicated that EPS production of strain 5.18 was a response to stress condition, while the
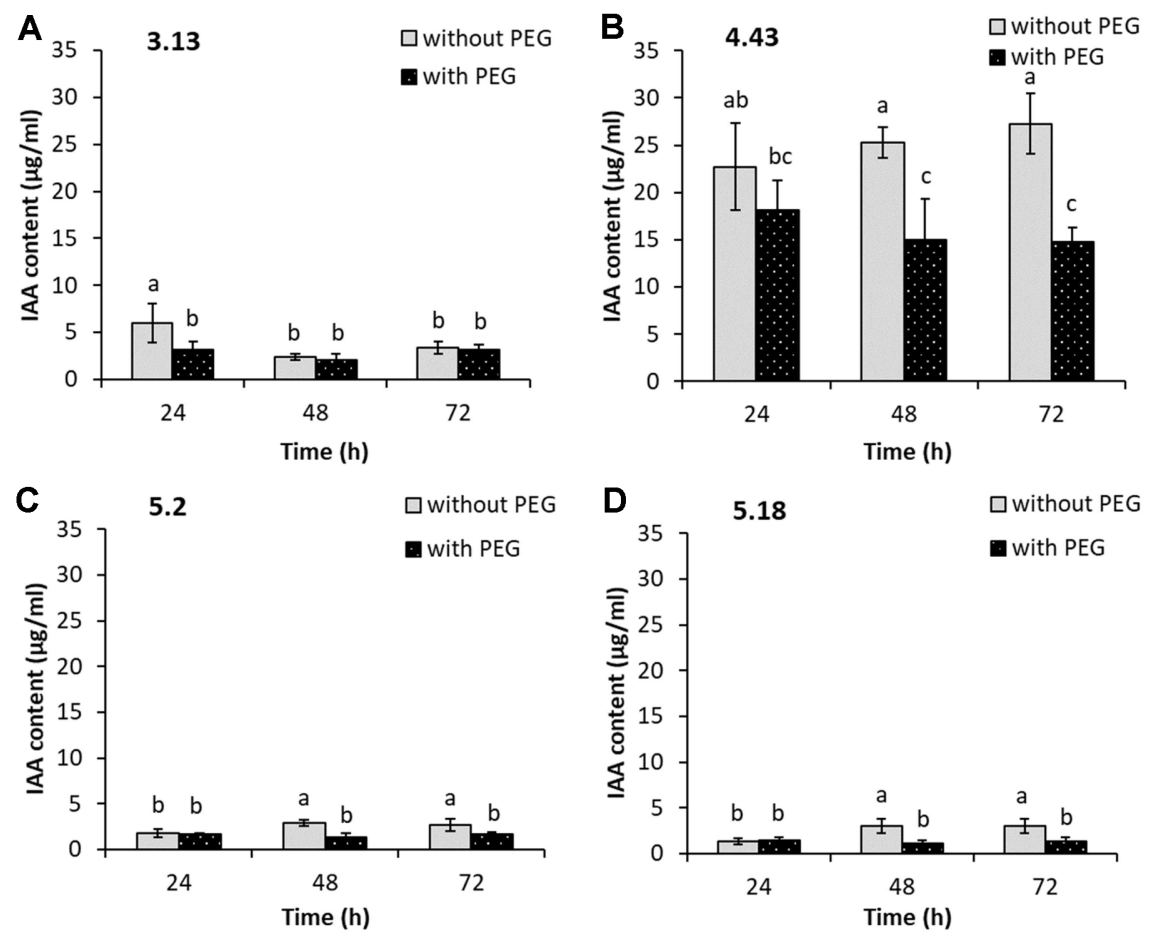

Fig. 1. Amount of indole acetic acid from endophytic bacteria (A) isolate 3.13, (B) isolate 4.43, (C) isolate 5.2, and (D) isolate 5.18 grown in nutrient broth with or without PEG $20 \%$ at 24,48 , and $72 \mathrm{~h}$.

Different letters are significantly different in each graph by LSD at $p<0.05$. 

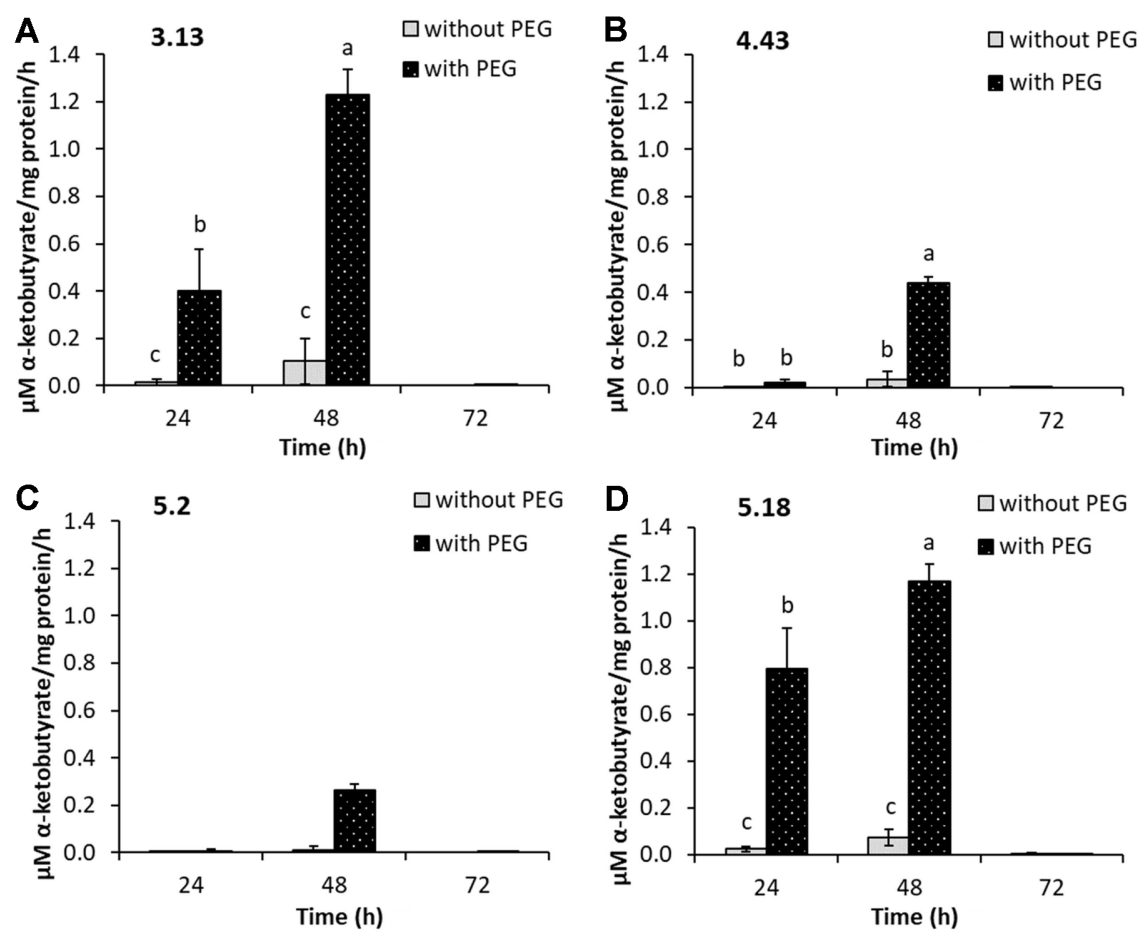

Fig. 2. Amount of 1-aminocyclopropane-1-carboxylate deaminase from endophytic bacteria (A) isolate 3.13 , (B) isolate 4.43, (C) isolate 5.2, and (D) isolate 5.18 grown in medium with or without PEG 20\% at 24, 48, and $72 \mathrm{~h}$.

Different letters are significantly different in each graph by LSD at $p<0.05$.

proline production of these endophytic bacteria was not the result of stress conditions.

\section{Endophytic Bacteria Promoting Plant Growth Depending on Water Deficit Levels}

The experiment was designed to provoke drought stress by controlling the availability of water in soil. At 30 days after planting, the soil contained $12-13 \%$ of moisture content, close to the field capacity of soil $(14.77 \%)$. This level decreased when the water was limited after 60 days of planting (Fig. 3), giving $10 \%$ and $7 \%$ of moisture content for $2 / 3 \mathrm{AW}$ and $1 / 3 \mathrm{AW}$, respectively, compared with the permanent wilting point of soil $(3.71 \%)$. This data indicates that water was maintained at drought stress levels

Table 1. Carbohydrate content in Exopolysaccharide (EPS) and Proline production of the endophytic bacteria isolates 3.13, 4.43, 5.2, and 5.18 grown in nutrient broth with and without PEG20\% at $96 \mathrm{~h}$ for EPS and $24 \mathrm{~h}$ for proline.

\begin{tabular}{ccccc}
\hline \multirow{2}{*}{ Condition } & Isolate & Glucose content $(\mu \mathrm{g} / \mathrm{ml})$ & \multicolumn{2}{c}{ Proline accumulation $(\mu \mathrm{g} / \mathrm{ml})$} \\
\cline { 4 - 5 } No PEG 20\% & 3.13 & $0.39 \pm 0.08^{\mathrm{d}}$ & $0.29 \pm 0.01^{\mathrm{e}}$ & \multicolumn{2}{c}{ Supernatant } \\
& 4.43 & $0.55 \pm 0.03^{\mathrm{cd}}$ & $1.21 \pm 0.11^{\mathrm{b}}$ & $1.35 \pm 0.03 \pm 0.17^{\mathrm{b}}$ \\
& 5.2 & $0.37 \pm 0.09^{\mathrm{d}}$ & $0.32 \pm 0.03^{\mathrm{e}}$ & $0.43 \pm 0.02^{\mathrm{d}}$ \\
& 5.18 & $0.78 \pm 0.05^{\mathrm{b}}$ & $0.81 \pm 0.02^{\mathrm{c}}$ & $0.66 \pm 0.03^{\mathrm{c}}$ \\
PEG 20\% & 3.13 & $0.40 \pm 0.06^{\mathrm{d}}$ & $0.32 \pm 0.00^{\mathrm{e}}$ & $1.02 \pm 0.04^{\mathrm{b}}$ \\
& 4.43 & $0.49 \pm 0.15^{\mathrm{c}}$ & $1.82 \pm 0.06^{\mathrm{a}}$ & $1.38 \pm 0.05^{\mathrm{a}}$ \\
\%CV & 5.2 & $0.39 \pm 0.10^{\mathrm{d}}$ & $0.32 \pm 0.01^{\mathrm{e}}$ & $0.42 \pm 0.01^{\mathrm{d}}$ \\
& 5.18 & $1.83 \pm 0.10^{\mathrm{a}}$ & $0.61 \pm 0.00^{\mathrm{d}}$ & $0.71 \pm 0.05^{\mathrm{c}}$ \\
\end{tabular}

Different letters in each column are significantly different at $p<0.01$ probability levels by least significant difference (LSD) test and coefficient of variation (CV) values. 


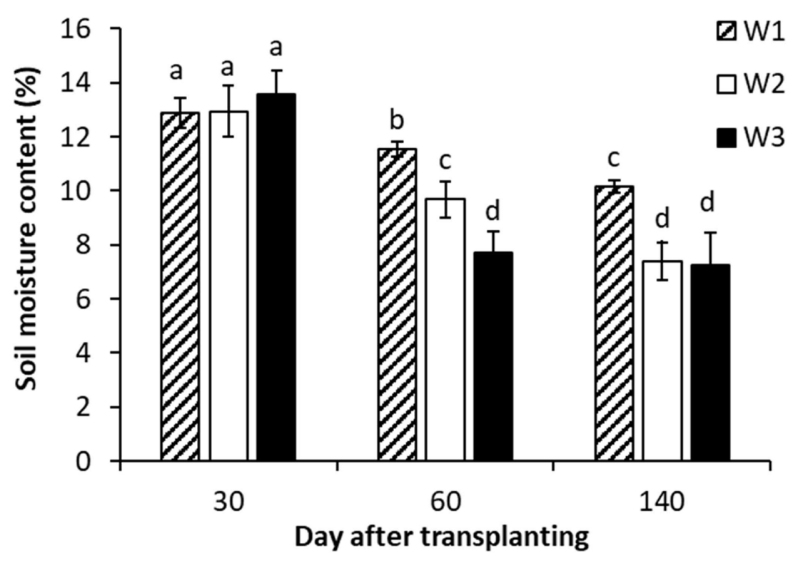

Fig. 3. Percentage of soil moisture content during transplanting. The water was controlled in 3 levels which were full watering equivalent to the crop water requirement (W1), 2/3 and $1 / 3$ of the crop water requirement (W2 and W3, respectively). Different letters are significantly different by LSD at $p<0.05$.

throughout the experiment.

The endophytic bacteria, strain 3.13 and 5.18 showed no significant benefit to plant height under well-watered conditions (W1) compared with control, except for strain 4.43 which promoted plant height better than others (Fig. 4). Plant height reduced the more the water supply was limited. At this point (W3), the height was significantly greater in treatments of inoculated endophytic bacteria compared with non-inoculation. The best strain for promoting plant height in drought was 3.13. In other measures of plant growth under drought, strain 4.43 promoted significantly the highest fresh shoot weight in W3, while the highest fresh root weight was achieved by strain 3.13 in W2 at 140 days. According to total fresh weight, strain 3.13 and 5.18 enhanced plant fresh weight under W2 at 60 days (Fig. 5A); also strain 3.13 and 4.43 increased total fresh weight under W2 and W3, respectively, at 140 days (Fig. 5B). It is clear that endophytic bacteria helped the plant to increase fresh shoot and root weight compared to non-inoculation, particularly in drought conditions. The outstanding strain was 3.13, which promoted root and shoot dry weight under W2 and W3 at 60 days (Fig. 5C) and in W2 at 140 days (Fig. 5D). There was no significant difference of total dry weight of inoculated plants that showed better than un-inoculated plants with the endophytic bacteria at 140 days under W1 and W2, except strain 3.13 (Fig. 5D). Under drought (W3), the endophytic bacteria improved plant dry weight significantly compared with control in W3, particularly strain 4.43 . The 4.43 and 3.13 strains confirmed to promote

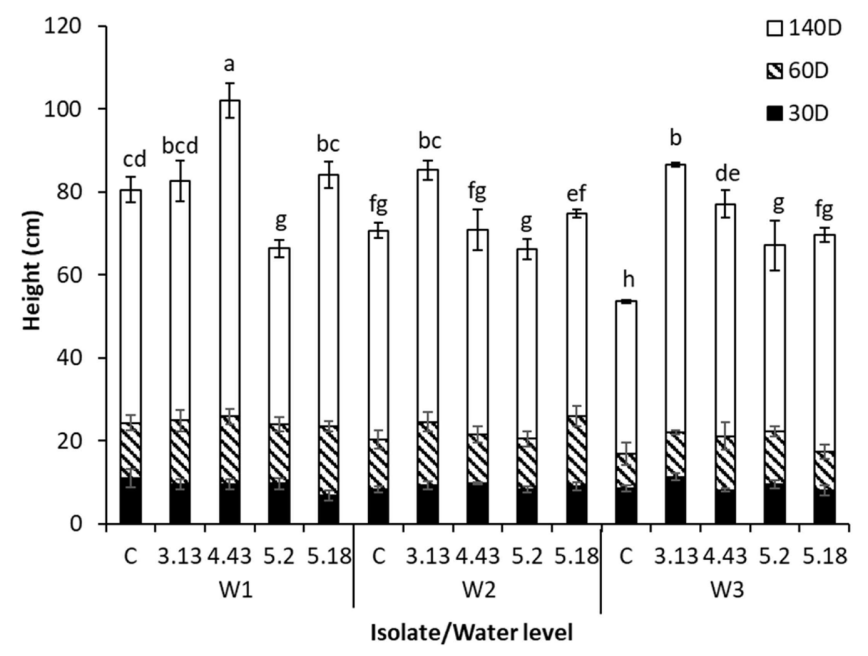

Fig. 4. Height of Jerusalem artichoke under planting by water limitation (W1 = 100\% AW (FC), W2 = 2/3 AW, W3 = 1/3 $\mathrm{AW}$ ) with inoculation of endophytic bacteria (isolate 3.13 , $4.43,5.2,5.18$ ) and control without bacteria (C).

Different letters indicated significant differences in total height at 140 days of planting by factorial analysis with LSD at $p<0.05$.

plant weight under drought stress by showing the highest total fresh and dry weight.

\section{Effects of Endophytic Bacteria on Root and Leaf Growth} Traits of Jerusalem Artichoke under Water Deficit

All strains of endophytic bacteria affected root growth, increasing root length and root diameter under drought in W3 at harvest times (Fig. 6) significantly compared to control in W3. Strain 3.13 strongly promoted root length under W2 and W3 conditions starting from 60 days until 140 days. The endophytic bacteria showed no significantly improvement in root growth under W1 at 60 and 140 days, except for 3.13 and 5.18 strains which enhanced root length in W1 at 140 days. The results showed similar trends in the effects of endophytic bacteria on root volume and root surface area under drought (Fig. S1). These effects demonstrate the relationship between root growth and endophytic bacteria; endophytic bacteria had no significant effect on root length, root diameter, root volume and root surface at well-watered conditions (W1). At the beginning of water limitation (60 days of planting), endophytic bacteria showed more effect on root growth under W2; the best strain was strain 3.13 that showed significant effects on root parameters better than control in W2 and W3. In contrast, they had significant effects on all root parameters at harvest time (Table 2). Water levels had direct effects on 

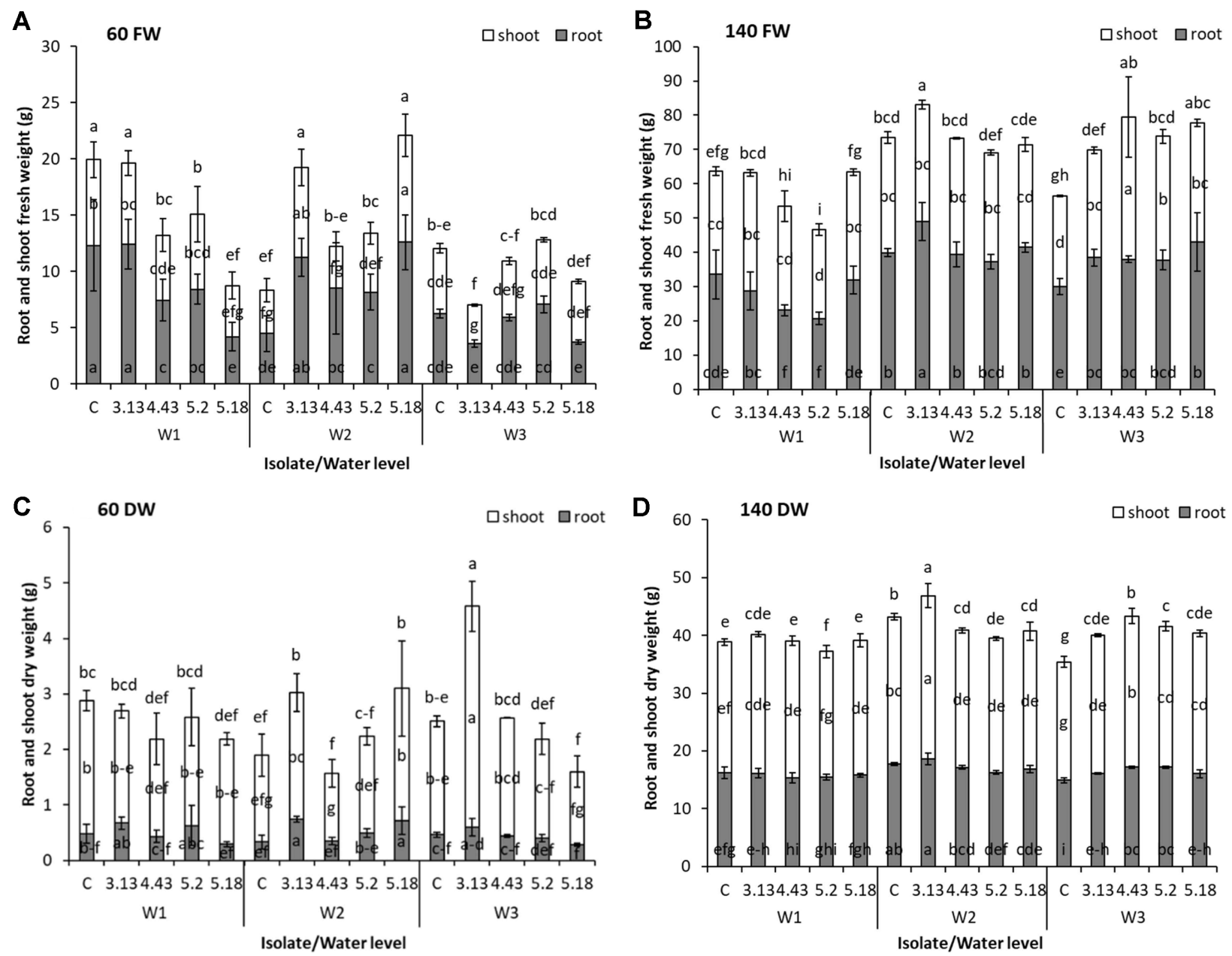

Fig. 5. Total fresh and dry weight of Jerusalem artichoke under planting by water limitation (W1 = 100\% AW (FC), W2 = 2/3 AW, $\mathrm{W} 3=1 / 3 \mathrm{AW}$ ) with inoculation of endophytic bacteria (isolate $3.13,4.43,5.2,5.18$ ) and control without bacteria (C).

Root and shoot fresh weight at 60 days (A) and 140 days (B) after transplanting; root and shoot dry weight at 60 days (C) and 140 days (D) after transplanting. Different letters indicated significant differences in root, shoot and total root and shoot weight by factorial analysis with LSD at $p<0.05$.

Table 2. Relationship between the endophytic bacteria and root physiology under 3 levels of water availability at 60 days and the harvest time (140 days).

\begin{tabular}{|c|c|c|c|c|c|c|c|c|c|}
\hline \multirow{2}{*}{ SOV } & \multirow{2}{*}{ Df } & \multicolumn{4}{|c|}{60 days of planting } & \multicolumn{4}{|c|}{140 days of planting } \\
\hline & & RL & $\mathrm{RD}$ & RV & RS & RL & RD & RV & RS \\
\hline REP & 3 & $6.42 \mathrm{E}+07$ & 0.37 & 1.46 & $0.24 \mathrm{E}+06$ & $3.68 \mathrm{E}+07$ & 0.76 & 14.59 & $0.11 \mathrm{E}+07$ \\
\hline $\mathrm{W}$ & 2 & $1.15 \mathrm{E}+07^{*}$ & 0.51 & $5.45^{*}$ & $0.57 \mathrm{E}+06$ & $2.35 \mathrm{E}+07^{* *}$ & $10.84^{* *}$ & $174.25^{* *}$ & $3.26 \mathrm{E}+07^{* *}$ \\
\hline I & 4 & $7.39 \mathrm{E}+07$ & 0.55 & $3.77^{*}$ & $0.56 \mathrm{E}+06$ & $2.00 \mathrm{E}+07^{* *}$ & $2.09^{*}$ & $54.74^{* *}$ & $2.54 \mathrm{E}+07^{* *}$ \\
\hline WxI & 8 & $1.16 \mathrm{E}+07^{* *}$ & $1.25^{* *}$ & $8.85^{* *}$ & $1.17 \mathrm{E}+06^{* *}$ & $5.40 \mathrm{E}+07^{* *}$ & $2.23^{* *}$ & $59.48^{* *}$ & $0.59 \mathrm{E}+07^{* *}$ \\
\hline$F$ for WxI & & 4.55 & 4.59 & 6.42 & 5.24 & 2.96 & 3.79 & 5.04 & 3.67 \\
\hline$\% \mathrm{CV}$ & & 34.50 & 33.07 & 35.38 & 35.00 & 13.43 & 13.26 & 17.67 & 14.82 \\
\hline
\end{tabular}

SOV: Source of variation; REP: Replication; W: level of water availability; I: bacterial isolates; Df: Degree of freedom; RL: Root length; RD: Diameter of root; RV: Root volume; RS: Root surface area.

The numbers are mean square values from factorial analysis with $\mathrm{F}$ test and coefficient of variation (CV). Significances mean that each SOV showed significant differences in plant parameters at $p<0.05\left(^{*}\right)$ and $p<0.01(* *)$. 
A
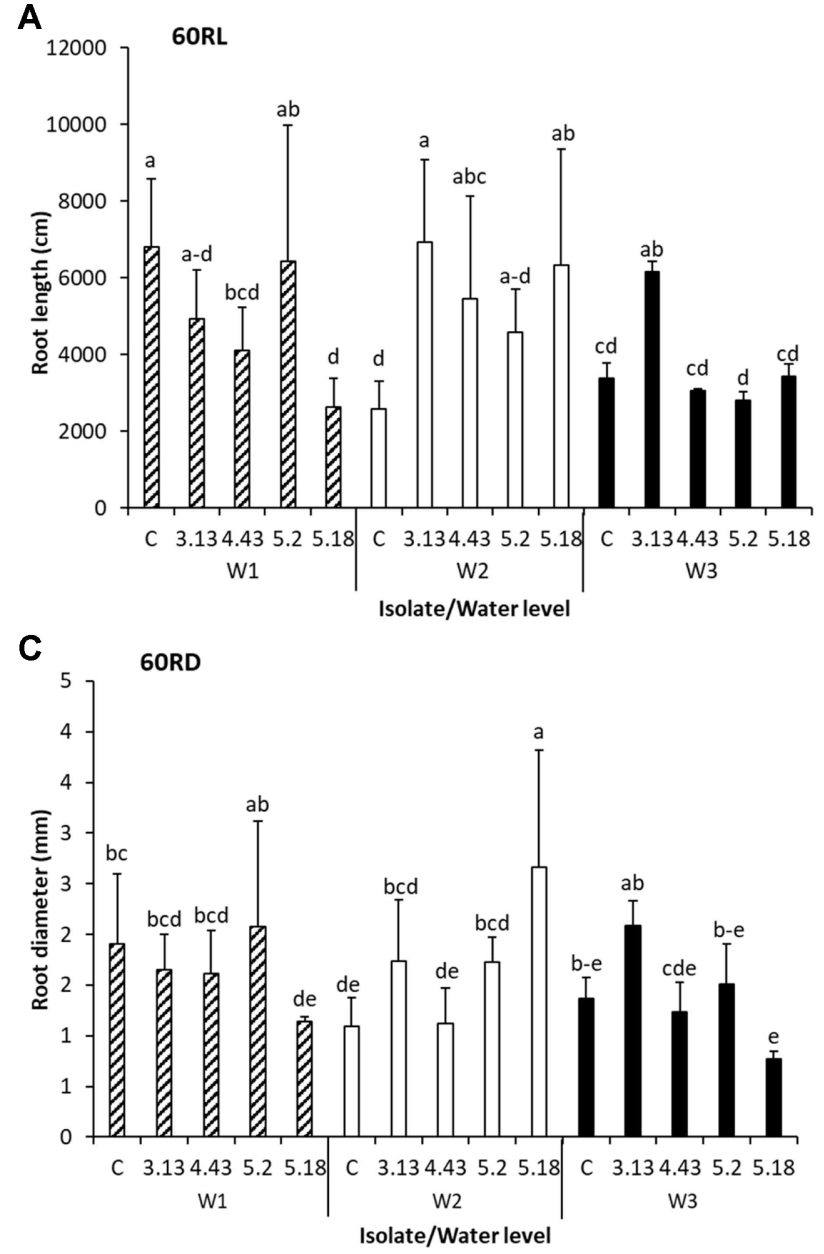
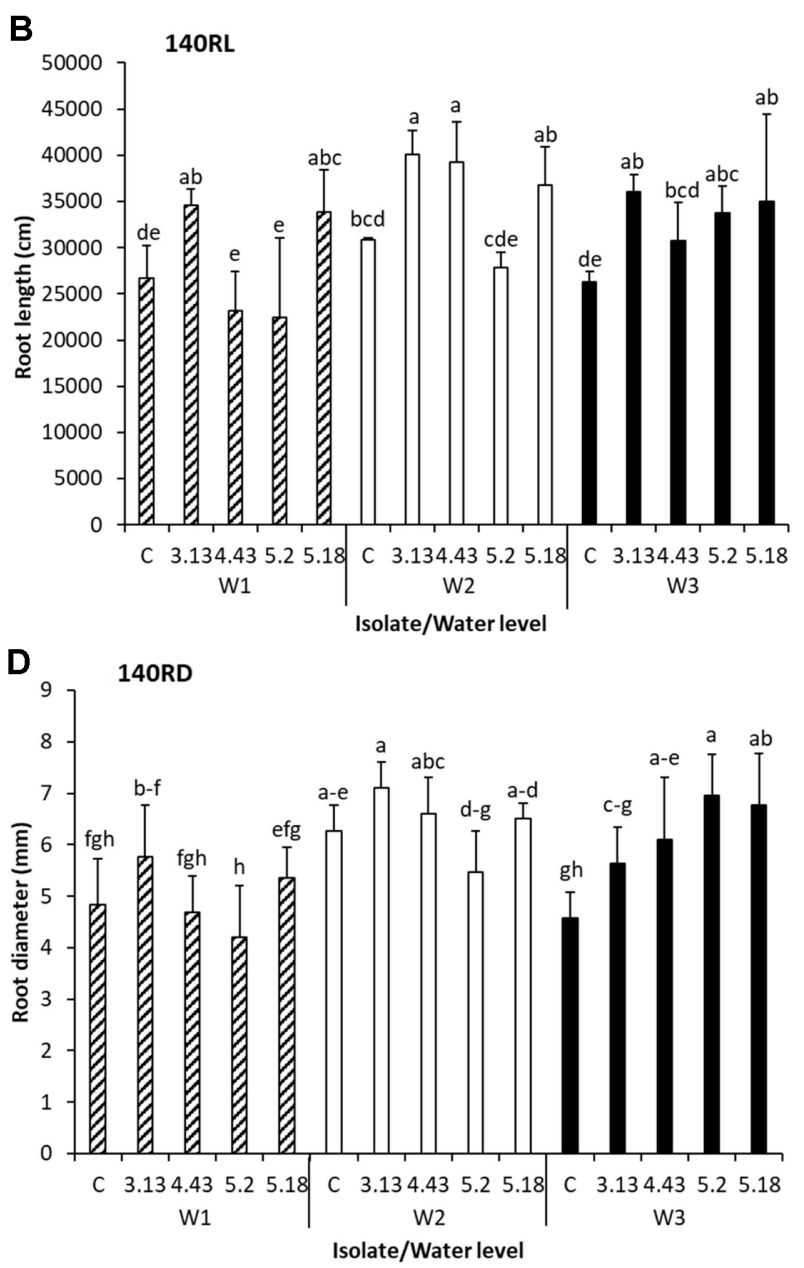

Fig. 6. Root length (A, B) and root diameter (C, D) of Jerusalem artichoke under planting by water limitation $(\mathrm{W} 1=100 \% \mathrm{AW}$ $(\mathrm{FC}), \mathrm{W} 2=2 / 3 \mathrm{AW}, \mathrm{W} 3=1 / 3 \mathrm{AW}$ ) with inoculation of endophytic bacteria (isolate $3.13,4.43,5.2,5.18$ ) and control without bacteria (C) at 60 and 140 days after transplanting.

Different letters indicated significant differences in length and diameter by factorial analysis with LSD at $p<0.05$.

Table 3. Relationship between the endophytic bacteria and leaf functions for light and water usage under 3 level of water availability at 60 days and the harvest time (140 days).

\begin{tabular}{|c|c|c|c|c|c|c|c|c|c|c|c|c|c|c|c|}
\hline \multirow{2}{*}{ SOV } & \multirow{2}{*}{ Df } & \multicolumn{7}{|c|}{60 days of planting } & \multicolumn{7}{|c|}{140 days of planting } \\
\hline & & SPAD & LA & $\mathrm{Pn}$ & WUE & Gs & $\operatorname{Tr}$ & RWC & SPAD & LA & $\mathrm{Pn}$ & WUE & Gs & $\operatorname{Tr}$ & RWC \\
\hline REP & 3 & 2.13 & 3124 & 2.90 & 0.21 & 0.00 & 0.05 & 11.57 & 5.51 & $1.98 \mathrm{E}+05^{* *}$ & 47.50 & 0.91 & 0.00 & 0.61 & 81.70 \\
\hline W & 2 & 6.94 & 448 & $47.25^{* *}$ & 0.06 & $0.06^{* *}$ & $0.44^{* *}$ & $231.93^{* *}$ & 13.89 & $5.94 \mathrm{E}+05^{* *}$ & $59.28^{*}$ & 0.60 & $0.07^{* *}$ & $3.97^{* *}$ & $130.33^{*}$ \\
\hline I & 4 & 8.93 & $25582^{* *}$ & $15.13^{* *}$ & $0.51^{* *}$ & $0.01^{* *}$ & $0.41^{* *}$ & 60.84 & $15.87^{*}$ & $5.18 \mathrm{E}+05^{* *}$ & 7.77 & 0.10 & $0.03^{* *}$ & 0.52 & $137.90^{* *}$ \\
\hline WxI & 8 & $31.27^{* *}$ & $13448^{* *}$ & $12.50^{* *}$ & $0.81^{* *}$ & $0.01^{* *}$ & $0.20^{* *}$ & $170.86^{* *}$ & $38.08^{* *}$ & $6.56 \mathrm{E}+05^{* *}$ & 13.30 & 0.31 & $0.00^{*}$ & 0.61 & $129.46^{* *}$ \\
\hline$F$ for $W x I$ & & 6.40 & 5.28 & 7.59 & 7.40 & 6.30 & 5.16 & 5.38 & 7.14 & 13.87 & 2.05 & 1.77 & 2.18 & 1.47 & 3.73 \\
\hline$\% \mathrm{CV}$ & & 7.35 & 24.00 & 5.78 & 6.11 & 8.88 & 4.81 & 7.82 & 6.39 & 7.41 & 17.02 & 10.81 & 17.16 & 18.34 & 8.08 \\
\hline
\end{tabular}

SOV: Source of variation; REP: Replication; W: level of water availability; I: bacterial isolates; Df: Degree of freedom; SPAD: chlorophyll content; LA: leaf area; Pn: Photosynthetic rate; WUE: Water use efficiency; Gs: Stomatal conductance; Tr: Transpiration rate; RWC: Relative water content.

The numbers are mean square values from factorial analysis with $\mathrm{F}$ test and coefficient of variation (CV). Significances mean that each SOV showed significant differences in plant parameters at $p<0.05\left({ }^{*}\right)$ and $p<0.01(* *)$. 
Table 4. Tuber fresh weight (TFW), Tuber dry weight (TDW) and Tuber number (TN) of Jerusalem artichoke at 140 days after transplanting with the endophytic bacteria under different water levels.

\begin{tabular}{|c|c|c|c|c|c|c|c|c|c|}
\hline \multirow[b]{2}{*}{ Isolate } & \multicolumn{3}{|c|}{ W1 } & \multicolumn{3}{|c|}{ W2 } & \multicolumn{3}{|c|}{ W3 } \\
\hline & $\begin{array}{c}\text { TFW } \\
\text { (g plant }^{-1} \text { ) }\end{array}$ & $\begin{array}{c}\text { TDW } \\
\text { (g plant }^{-1} \text { ) }\end{array}$ & $\begin{array}{c}\text { TN } \\
\left(\text { plant }^{-1}\right)\end{array}$ & $\begin{array}{c}\text { TFW } \\
\text { (g plant }^{-1} \text { ) }\end{array}$ & $\begin{array}{c}\text { TDW } \\
\left.\text { (g plant }^{-1}\right)\end{array}$ & $\begin{array}{c}\mathrm{TN} \\
\left(\text { plant }^{-1}\right)\end{array}$ & $\begin{array}{c}\text { TFW } \\
\text { (g plant }^{-1} \text { ) }\end{array}$ & $\begin{array}{c}\text { TDW } \\
\left.\text { (g plant }^{-1}\right)\end{array}$ & $\begin{array}{c}\mathrm{TN} \\
\left(\text { plant }^{-1}\right)\end{array}$ \\
\hline Control & $27.78 \pm 1.22^{c}$ & $6.44 \pm 0.31^{\mathrm{c}}$ & $4.75 \pm 0.47^{c}$ & $32.33 \pm 0.93^{\mathrm{bc}}$ & $7.65 \pm 0.13^{\mathrm{ab}}$ & $6.00 \pm 0.82^{b}$ & $18.56 \pm 2.00^{\mathrm{d}}$ & $4.40 \pm 0.25^{\mathrm{d}}$ & $4.25 \pm 0.47^{\mathrm{d}}$ \\
\hline 3.13 & $49.42 \pm 10.33^{\mathrm{a}}$ & $10.01 \pm 0.85^{\mathrm{a}}$ & $5.75 \pm 0.42^{\mathrm{b}}$ & $35.57 \pm 1.89^{\mathrm{ab}}$ & $8.47 \pm 1.35^{\mathrm{a}}$ & $6.00 \pm 0.82^{b}$ & $31.95 \pm 0.74^{\mathrm{b}}$ & $6.34 \pm 0.30^{\mathrm{ab}}$ & $6.00 \pm 0.00^{b}$ \\
\hline 4.43 & $40.33 \pm 4.22^{\mathrm{b}}$ & $10.03 \pm 1.24^{\mathrm{a}}$ & $7.00 \pm 0.00^{a}$ & $39.06 \pm 6.03^{\mathrm{a}}$ & $7.07 \pm 0.64^{\mathrm{b}}$ & $6.75 \pm 0.47^{b}$ & $39.05 \pm 4.74^{\mathrm{a}}$ & $9.19 \pm 0.99^{\mathrm{a}}$ & $8.25 \pm 0.47^{a}$ \\
\hline 5.2 & $40.73 \pm 2.10^{\mathrm{b}}$ & $7.52 \pm 0.80^{\mathrm{bc}}$ & $6.75 \pm 0.47^{a}$ & $30.06 \pm 2.28^{c}$ & $5.76 \pm 0.07^{c}$ & $3.75 \pm 0.94^{c}$ & $30.78 \pm 0.43^{b}$ & $6.74 \pm 0.20^{\mathrm{b}}$ & $5.00 \pm 0.00^{c}$ \\
\hline 5.18 & $38.96 \pm 1.71^{\mathrm{b}}$ & $8.40 \pm 0.28^{\mathrm{b}}$ & $7.25 \pm 0.47^{\mathrm{a}}$ & $40.49 \pm 1.20^{\mathrm{a}}$ & $8.12 \pm 0.35^{\mathrm{ab}}$ & $8.00 \pm 0.00^{a}$ & $25.69 \pm 2.53^{c}$ & $5.66 \pm 0.29^{c}$ & $6.00 \pm 0.00^{b}$ \\
\hline$\% \mathrm{CV}$ & 14.12 & 10.19 & 7.67 & 9.49 & 9.33 & 9.10 & 6.61 & 7.80 & 4.64 \\
\hline
\end{tabular}

Values with different letters are significantly different at $p<0.01$ probability levels by least significant difference (LSD) test and coefficient of variation (CV) values. $\mathrm{W} 1=100 \% \mathrm{AW}(\mathrm{FC}), \mathrm{W} 2=2 / 3 \mathrm{AW}, \mathrm{W} 3=1 / 3 \mathrm{AW}$.

root parameters; thus, a combination of endophytic bacteria and water levels gave significant differences in root growth.

Leaf growth traits were determined by chlorophyll content, leaf area and photosynthetic rate - including stomatal conductance, transpiration rate, water use efficiency and relative water content. The efficiency of leaf functions under drought combined with endophytic bacteria was then analysed. Only chlorophyll content (SPAD) showed no significant relation to the presence of endophytic bacteria and varying water levels, but the combination of endophytic bacteria and water levels had effects on SPAD at 60 days of planting (Table 3). At harvest time, photosynthetic rate, water use efficiency and transpiration rate showed no relationship with endophytic bacteria, water levels or a combination of both. However, the leaf area increased in plants inoculated with endophytic bacteria, leading to SPAD and relative water content being higher than control when under W3, particularly in strain 4.43 (Table S1). Meanwhile, different water levels had an effect on leaf area, photosynthetic rate, stomatal conductance and transpiration rate; all were reduced under drought conditions.

\section{Yield Enhancement under Water Deficit by Endophytic Bacteria}

The endophytic bacteria strongly promoted yield of Jerusalem artichoke under well-watered (W1) and W3, increasing tuber number and tuber fresh and dry weight (Table 4). Strains 3.13 and 4.43 had high potential to increase yields in well-watered conditions, while strain 4.43 was outstanding for yield improvement in W3. Under W2, tuber number and tuber fresh weight showed the highest yield in the plants inoculated with strain 5.18 and 4.43 , in order. Strain 4.43 had the greatest inulin content under W1 and W2. Strain 3.13 showed the highest inulin in W3 (Table 5). However, the water deficit had strong effect on inulin production, resulting in a reduction of inulin relative to the declining water levels. Interesting, strains $3.13,4.43$ and 5.2 still promoted inulin production under

Table 5. Harvest Index (HI) and Inulin content (IN) of Jerusalem artichoke at 140 days after transplanting with the endophytic bacteria under different water levels.

\begin{tabular}{|c|c|c|c|c|c|c|}
\hline \multirow{2}{*}{ Isolate } & \multicolumn{2}{|c|}{ W1 } & \multicolumn{2}{|c|}{ W2 } & \multicolumn{2}{|c|}{ W3 } \\
\hline & $\mathrm{HI}$ & IN (\%) & $\mathrm{HI}$ & IN (\%) & $\mathrm{HI}$ & IN (\%) \\
\hline Control & $0.09 \pm 0.00^{c}$ & $69.30 \pm 3.47^{\mathrm{d}}$ & $0.10 \pm 0.00^{b}$ & $62.01 \pm 5.60^{b}$ & $0.07 \pm 0.00^{\mathrm{c}}$ & $60.14 \pm 4.59^{b}$ \\
\hline 3.13 & $0.13 \pm 0.01^{\mathrm{a}}$ & $81.47 \pm 7.24^{\mathrm{bc}}$ & $0.10 \pm 0.01^{\mathrm{ab}}$ & $89.29 \pm 11.96^{\mathrm{a}}$ & $0.09 \pm 0.00^{\mathrm{b}}$ & $69.46 \pm 7.77^{\mathrm{a}}$ \\
\hline 4.43 & $0.14 \pm 0.01^{\mathrm{a}}$ & $92.83 \pm 4.12^{\mathrm{a}}$ & $0.10 \pm 0.01^{\mathrm{b}}$ & $94.76 \pm 4.82^{\mathrm{a}}$ & $0.12 \pm 0.01^{\mathrm{a}}$ & $56.10 \pm 7.80^{b}$ \\
\hline 5.2 & $0.11 \pm 0.01^{\mathrm{bc}}$ & $73.92 \pm 6.12^{\mathrm{cd}}$ & $0.08 \pm 0.00^{c}$ & $90.00 \pm 3.08^{\mathrm{a}}$ & $0.09 \pm 0.00^{b}$ & $14.00 \pm 2.50^{c}$ \\
\hline 5.18 & $0.11 \pm 0.00^{\mathrm{b}}$ & $89.98 \pm 7.47^{\mathrm{ab}}$ & $0.11 \pm 0.00^{\mathrm{a}}$ & $61.58 \pm 9.15^{\mathrm{b}}$ & $0.08 \pm 0.00^{\mathrm{b}}$ & $61.29 \pm 4.49^{\mathrm{ab}}$ \\
\hline$\% \mathrm{CV}$ & 9.69 & 7.87 & 6.39 & 10.56 & 7.62 & 10.38 \\
\hline
\end{tabular}

Values with different letters are significantly different at $p<0.01$ probability levels by least significant difference (LSD) test and coefficient of variation (CV) values. W1 $=100 \% \mathrm{AW}(\mathrm{FC}), \mathrm{W} 2=2 / 3 \mathrm{AW}, \mathrm{W} 3=1 / 3 \mathrm{AW}$ 
W2. All strains of endophytic bacteria improved plant harvest index under normal and drought conditions, with strains 3.13 and 4.43 showing high potential.

Endophytic bacteria promote plant growth in normal or stress conditions by producing bioactive compounds which act as signals. These signals control metabolite production and induce or inhibit plant immune responses to help the growth or survival of the plant host. Properties of the 4 potential strains of endophytic bacteria were determined by comparing water stress to normal in vitro. Strain 4.43 produced the highest IAA, but less IAA under water limitation in medium (PEG medium). The PEG is able to capture water molecules and bind protein, amino acids and hydrophobic site of molecules [17], leading to less interaction of molecules; thus, tryptophan molecules might bind with PEG and not be free for bacteria uptake. This indicated that strain 4.43 was able to produce IAA at low concentrations of tryptophan. Lower IAA production under stress conditions might accelerate plant growth better than high concentrations of IAA, which have negative effects on plant growth. Strain 3.13 and 5.18 produced high ACC deaminase activity under stress condition, in complete contrast to another report which showed higher ACC deaminase production under nonstress than stress condition [10]. Our findings indicated that ACC deaminase of both isolates were induced under water limitation or stress condition. The ACC deaminase is an inducible enzyme depending on the presence or absence of oxygen, substrate (ACC) concentration and accumulation of product ( $\alpha$-ketobutyrate) by regulation of acdS gene [18]. Two regulation systems of acdS gene were found in Pseudomonas putida and related bacteria and nitrogen fixing Mesorhizobium sp. Many different bacterial genera are still unknown for acdS gene regulation, which may be involved in a downstream element of the gene. The evidence of acdS gene regulation in Bacillus is not clear; no acdS gene was amplified in Bacillus and no database of acdS gene of Bacillus was deposited in NCBI [19]. Thus, it is necessary to study the mechanism of ACC deaminase regulation for 3.13 and 5.18 strains. The ACC deaminase producing bacteria benefitted plants in stress, e.g. drought, salt, flooding, as the enzyme degraded ACC, which is a precursor of ethylene. Low levels of ethylene in plant corresponds with increased growth by enhancing root system, shoot and biomass.

EPS production is another property which helps bacteria and plant survive in drought. It does so by enhancing water retention and regulating the diffusion of organic carbon sources $[7,20]$. The endophytic bacteria producing
EPS might enhance attachment and colonization to plant root providing microenvironments that hold water and dry out more slowly [21]; thus, plants can tolerate drought and maintain growth. Moreover, the endophytic bacteria may induce drought response in plants to produce substances that protect plants from drought. Pseudomonas fluorescens produced EPS could induce ajmalicine production in Catharanthus roseus for drought response [22]. Strain 5.18 showed the highest EPS production in stress conditions, leading to heat tolerance. This isolate might produce EPS to protect itself from losing water inside the cells; thus, cells could survive in arid conditions or high temperatures. The osmolytes, such as proline, free amino acids, sugars, are keys to protect bacteria by boosting the stability of proteins and membrane under water limitation [23]. In this work, all endophytic bacteria produced proline accumulated in cells and released in environments. It is likely that the proline accumulation of the endophytic bacteria may not be a response to water limitation but rather a normal product in amino acid synthesis for cell growth and survival.

Jerusalem artichoke is classified as a drought tolerant plant depending on its varieties; for instant, JA5, JA60 and JA125 showed high drought tolerance index (DTI) values for root parameters and could stabilize tuber yield by having capability for water adsorption under drought stress [24]. In contrast, HEL65 showed low DTI values under mild and severe water stress (50\% and $25 \%$ of AW, respectively). Microorganisms living in rhizosphere and endosphere are able to improve plant growth. Thus, the genotype of HEL65 was used in this study to demonstrate plant growth promotion under drought stress by the endophytic bacteria. These bacteria were isolated from Jerusalem artichoke host and used as the native strains to investigate their capability to improve plant response in water stress. Under $50 \%$ and $25 \% \mathrm{AW}$, Jerusalem artichoke showed a reduction of root length, root diameter, root volume and root area, but increased in root/shoot ratio. The correlation was significant between root traits and tuber weight in drought condition [24]. This study found a significant enhancement of plant growth under drought in the case of inoculation of endophytic bacteria. These benefits were clearly evident in W3 at harvest time, particularly height, weight, root traits and yields, showing a significant relationship between the endophytic bacteria and these parameters at a level of $p<0.01$ (Table 2). The properties of the endophytic bacteria, particular IAA and ACC deaminase production, were involved in growth promotion. Strain 3.13 was outstanding in ACC deaminase production, inducing root growth from less ethylene 
production in plant, increasing height and total weight under water deficit. Strain 4.43 was an excellent IAA producer, showing the longest root length under mild drought (W2). These findings suggest that ACC deaminase is an important mechanism for endophytic bacteria to help plants under drought; moreover, that IAA production of the endophytic bacteria is necessary for plant growth under either normal or stress conditions. Strain 3.13 was the best for promoting plant growth under drought as it could produce both ACC deaminase and IAA even though its IAA production was less than strain 4.43. This is because IAA activates plant transcription of ACC synthase, resulting in high levels of ACC and hence greater amounts of ethylene in the plant [25]. If bacteria have both IAA and ACC deaminase, as with strain 3.13, it can reduce ACC by ACC deaminase and use IAA to promote plant growth. According to the effects of endophytic bacteria on plant growth, the correlation of fresh and dry weight was positively significant to root traits; particularly, the correlation coefficient was high between fresh root weight and root diameter $(r=0.72)$, root volume $(r=0.73)$, root surface $(r=0.81)$ and root length $(r=0.85)$ on harvest day (140 days) under W3. This implied that the endophytic bacteria obtained IAA and inhibited the ethylene production with ACC deaminase, while also inducing root system development which could help to maintain high water uptake.

Strain 4.43 demonstrated significant effects on SPAD and LA, giving high values under W3 at 60 and 140 days. This strain 4.43 helped to promote leaf area and chlorophyll, leading to a high photosynthetic rate at 60 days, then declining at harvest time. The link between bacteria and plant for leaf functions is still not fully understood. It is possible that the endophytic bacteria help plants to maintain photosynthesis under drought, culminating in greater accumulation of sugars generated from photosynthesis. Sugars and carbohydrates play key roles for signaling and protecting plants under stress [26] as they are the major building structure and energy source for biomass production and maintenance. Strain 4.43 produced the IAA molecule which is involved in expression of tricarboxylic acid cycle, glyoxylate shunt and amino acid biosynthesis [27], leading to biomass and yield induction.

The leaf area was correlated to fresh shoot weight $(\mathrm{r}=0.96)$, dry shoot weight $(\mathrm{r}=0.92)$, root diameter $(\mathrm{r}=0.64)$, root volume $(\mathrm{r}=0.53)$ and root surface $(\mathrm{r}=0.48)$, but not root length; while SPAD was correlated to leaf area $(r=0.59)$, height $(r=0.43)$, fresh shoot weight $(r=0.59)$, dry shoot weight $(r=0.53)$ under W3 at 140 days. It seems that the endophytic bacteria correlated with shoot weight more than root traits; furthermore, they had an effect on plant biomass. The stomatal conductance correlated with the transpiration rate $(\mathrm{r}=0.50)$ and the photosynthetic rate $(\mathrm{r}=0.65)$ under $\mathrm{W} 3$ at 60 days; these parameters were related to endophytic bacteria and the water levels at 60 days. These results did not concur with those of Vandoorne et al. [28], who reported that photosynthesis light phase (photosystem II efficiency and photochemical quenching) increased in chicory under drought; another author reported that photosynthesis was not related to stomatal effects [29]. It is evident that the function of endophytic bacteria within leaves requires further investigation.

Under W3, the fresh and dry weight of tuber clearly decreased in control compared with well-watered (W1), while endophytic bacteria strongly promoted weight and tuber numbers, showing higher yield than control under W1 and W3. Strain 4.43 was outstanding in yield promotion, leading to the highest harvest index under W3. According to the results, the height, weight, SPAD and leaf area correlated to yields, including tuber number, fresh and dry tuber weight. The root traits did not correlate to yields under W3, but there was a correlation with biomass. Plant weight and number of tubers positively correlated to sucrose, fructose and glucose levels, which are main parameters influencing the regulation of inulin metabolizing enzyme [30]. Endophytic bacteria may help plants to accumulate sugars, decreasing osmotic potential; in this case, sucrose might be the main signaling molecule for tuber production in Jerusalem artichoke. Strain 3.13 was found to obtain inulin hydrolysis and strain 5.18 obtained inulin synthesis [31]. This activity may create a source of sucrose or fructose in plants or be involved in plant inulin synthesis/degradation. Thus, endophytic bacteria demonstrated induction of inulin content under W1 compared with control. Under water stress, the sucrose:sucrose 1-fructosyltransferase (1-SST) and fructan:fructan 1-fructosyltransferase (1-FFT) for plant inulin synthesis reduced; in contrast, the fructan 1exohydrolase (1-FEH) for plant inulin hydrolysis slightly increased in chicory. There were no effects on inulin concentration as 1-SST is initiated in early state of seedling and 1-FEH likely does not contribute in depolymerization in vivo [28]. In this study, water deficit had no effect on inulin content in control. In contrast, inulin obviously reduced in the treatment of the endophytic bacteria under W3 compared with W1, but not significantly with the inulin of control in W3. The endophytic bacteria induced plant growth in response to drought for survival; the 
resource expense of growth may be the cause of decreasing inulin production.

Water deficit affected height, weight, root growth, leaf function and yield in Jerusalem artichoke; plants respond by increasing nutrient uptake, water adsorption, osmotic potential and maintaining activity inside the cells for survival. The endophytic bacteria associated with plant host were in symbiosis, giving metabolites for plant growth and defense. The drought response of these bacteria showed mainly in IAA production and ACC deaminase, which demonstrated the relationship between the endophytic bacteria and plant parameters. Both activities had effects on biomass, leading to higher yield. It remains unclear how EPS and proline production is related to the plant host. Strain 3.13 and 4.43 showed significant induction of plant growth and yield under severe drought (W3), while strain 5.2 and 5.18 had effects on some parameters. IAA seems to be an important signal molecule inside plant for the growth response system. Moreover, the relationship between the endophytic bacteria and yield is interesting; the bacteria may have some signal molecules, such as fructose, that induces inulin genes regulation under well-watered conditions. There should be further study on the role of bacteria for inulin promotion in drought conditions.

\section{Acknowledgments}

The authors thank for the research fund of Khon Kaen University under National Research Council of Thailand (Project no. 61003601) and also The Thailand Research Fund for providing financial support through the Senior Research Scholar Project of Prof. Dr. Sanun Jogloy (Project no. RTA6180002).

\section{Conflict of Interest}

The authors have no financial conflicts of interest to declare.

\section{References}

1. Mengel K. 1982. Factors of plant nutrient availability relevant to soil testing. Soil 64: 129-138.

2. Mahajan S, Tuteja N. 2005. Cold, salinity and drought stresses: an overview. Arch. Biochem. Biophys. 444: 139-158.

3. Aduldecha C, Kaewpradit W, Vorasoot N, Puangbut D, Jogloy S, Patanothai A. 2016. Effects of water regimes on inulin content and inulin yield of Jerusalem artichoke genotypes with different levels of drought tolerance. Turk. J. Agric. For. 40: 335-343.

4. Vurukonda SS, Vardharajula S, Shrivastava M, SkZ A. 2016. Enhancement of drought stress tolerance in crops by plant growth promoting rhizobacteria. Microbiol. Res. 184: 13-24.

5. Du H, Wu N, Fu J, Wang S, Li X, Xiao J, et al. 2012. A GH3 family member, OsGH3-2, modulates auxin and abscisic acid levels and differentially affects drought and cold tolerance in rice. J. Exp. Bot. 63: 6467-6480.

6. Glick BR, Cheng Z, Czarny J, Duan J. 2007. Promotion of plant growth by ACC deaminase-producing soil bacteria. Eur. J. Plant Pathol. 119: 329-339.

7. Wilkinson JF. 1958. The extracellular polysaccharides of bacteria. Bacteriol. Rev. 22: 46-73.

8. Hepper CM. 1975. Extracellular polysaccharides of soil bacteria, pp. 93-111. In Walker N (ed.), Soil microbiology, a critical review, Wiley, New York.

9. Khamwan S, Boonlue S, Riddech N, Jogloy S, Mongkolthanaruk W. 2018. Characterization of endophytic bacteria and their response to plant growth promotion in Helianthus tuberosus L. Biocatal. Agric. Biotechnol. 13: 153?159.

10. Ali SZ, Sandhya V, Rao LV. 2014. Isolation and characterization of drought-tolerant ACC deaminase and exopolysaccharide-producing fluorescent Pseudomonas sp. Ann. Microbiol. 64: 493-502.

11. Dubois M, Gilles KA, Hamilton JK, Rebers PT, Smith F. 1956. Colorimetric method for determination of sugars and related substances. Anal. Chem. 28: 350-356.

12. Bates LS, Waldren RP, Teare ID. 1973. Rapid determination of free proline for water-stress studies. Plant Soil 39: 205207.

13. Doorenbos J, Pruitt WO. 1992. Crop water requirement: calculation of crop water requirement, pp. 1-65. In Brouwer C, Heibloem $\mathrm{M}$ (eds.), Irrigation water management training manual no. 3, FAO of The United Nation, Italy.

14. Janket A, Jogloy S, Vorasoot N, Kesmala T, Holbrook C, Patanothai A. 2013. Genetic diversity of water use efficiency in Jerusalem artichoke (Helianthus tuberosus L.) germplasm. Aust. J. Crop Sci. 7: 1670-1681.

15. Saengkanuk A, Nuchadomrong S, Jogloy S, Patanothai A, Srijaranai S. 2011. A simplified spectrophotometric method for the determination of inulin in Jerusalem artichoke (Helianthus tuberosus L.) tubers. Eur. Food Res. Technol. 233: 609.

16. Namwongsa J, Boonlue S, Riddech N, Jogloy S, Mongkolthanaruk, W. 2018. The survival of endophytic bacteria isolated from Jerusalem artichoke in drought conditions. Int. J. Appl. Phys. Sci. 4: 59-68.

17. Arakawa T, Timasheff SN. 1985. Mechanism of poly(ethylene glycol) interaction with proteins. Biochemistry 24: 6756-6762.

18. Singh RP, Shelke GM, Kumar A, Jha PN. 2015. Biochemistry and genetics of ACC deaminase: a weapon to "stress ethylene" produced in plants. Front. Microbiol. 6: 937. 
19. Li Z, Chang S, Ye S, Chen M, Lin L, Li Y, et al. 2015. Differentiation of 1-aminocyclopropane-1-carboxylate (ACC) deaminase from its homologs is the key for identifying bacteria containing ACC deaminase. FEMS Microbiol. Ecol. 91: doi: $10.1093 /$ femsec/fiv112

20. Roberson EB, Firestone MK. 1992. Relationship between desiccation and exopolysaccharide production in soil Pseudomonas sp. Appl. Environ. Microbiol. 58: 1284-1291.

21. Bashan Y, Holguin G, de-Bashan LE. 2004. Azospirillumplant relationships: physiological, molecular, agricultural, and environmental advances. Can. J. Microbiol. 50: 521-577.

22. Jaleel CA, Manivannan P, Sankar B, Kishorekumar A, Gopi R, Somasundaram $\mathrm{R}$, et al. 2007. Pseudomonas fluorescens enhances biomass yield and ajmalicine production in Catharanthus roseus under water deficit stress. Colloids Surf. B. Biointerfaces. 60: 7-11.

23. Kogut M, Russell NJ. 1987. Life at the limits: considerations on how bacteria can grow at extremes of temperature and pressure, or with high concentrations of ions and solutes. Sci. Prog. 71: 381-399.

24. Ruttanaprasert R, Jogloy S, Vorasoot N, Kesmala T, Kanwar RS, Holbrook CC, et al. 2015. Root responses of Jerusalem artichoke genotypes to different water regimes. Biomass Bioenergy 81: 369-377.
25. Olanrewaju OS, Glick BR, Babalola OO. 2017. Mechanisms of action of plant growth promoting bacteria. World J. Microbiol. Biotechnol. 33: 197.

26. Bolouri-Moghaddam MR, Le RK, Rolland F, Van den Ende W. 2010. Sugar signaling and antioxidant network connections in plant cells. FEBS J. 277: 202-207.

27. Bianco C, Imperlini E, Calogero $R$, Senatore B, Pucci $P$, Defez R. 2006. Indole-3-acetic acid regulates the central metabolic pathways in Escherichia coli. Microbiology 152: 2421-2431.

28. Vandoorne B, Mathieu AS, Van den Ende W, Vergauwen $\mathrm{R}$ Périlleux C, Javaux M, et al. 2012. Water stress drastically reduces root growth and inulin yield in Cichorium intybus (var. sativum) independently of photosynthesis. J. Exp. Bot. 63: 4359-4373.

29. Monti A, Amaducci MT, Pritoni G, Venturi G. 2005. Growth, fructan yield, and quality of chicory (Cichorium intybus L.) as related to photosynthetic capacity, harvest time and water regime. J. Exp. Bot. 56: 1389-1395.

30. Van den Ende W, De Coninck B, Van Laere A. 2004. Plant fructan exohydrolases: a role in signaling and defense? Trends Plant. Sci. 9: 523-528.

31. Khamwan S, Mongkolthanaruk W. 2016. Exploring of the inulin synthesis gene of endophytic bacteria by the new degenerated primers. pp. 24-27. 6th Annual International Conference on Advances in Biotechnology Proceedings. 